\title{
Revisiting 'Translatability' and African Christianity: \\ The Case of the Christian Catholic Apostolic Church in Zion
}

The example of Christian Zionism in South Africa seems to perfectly illustrate the scholarly vogue for portraying Christianity in Africa as an eminently 'translatable' religion. Zionism - not to be confused with the Jewish movement focused on the state of Israel - is the largest popular Christian movement in modern Southern Africa, to which millions in South Africa, Swaziland, Lesotho, Mozambique, Botswana, Zimbabwe and Zimbabwe belong; by the 1960s, 21\% of Southern Africans were Zionist. ${ }^{1}$ However, with now over three thousand active Zionist churches in the Southern African region, there is no single Zionist organization. The biggest is the Zion Christian Church in northern South Africa, with six million members, while the vast majority of Zionist churches have between fifty and two hundred members. ${ }^{2}$ Adherents of this diffuse, decentralized movement have historically been drawn from South Africa's working-classes; today, Zionists are still perceived as representative of the rank of minimally educated, economically marginalized black South Africans. And although thus vastly diverse, a unifying feature of Zionists across this region is their emphasis on health and healing. Almost uniformly, a Zionist service centers on a healing event during which congregation members receive prayer from a 'prophet' for a physical, emotional or psychological ailment. Some churches still eschew both Western and African medicine in favor of exclusive reliance upon prayer. ${ }^{3}$

Both scholarship and popular perception have largely understood Zionism as a uniquely Southern African phenomenon, entirely indigenous to the region. The first study of Zionism was Swedish Lutheran missiologist Bengt Sundkler's 1948 Bantu Prophets in South Africa. ${ }^{4}$ Sundkler's book was a pioneering effort to take Zionists seriously. Previously dismissed as a superstitious corruption of Christianity; 'orthodox' Christianity was instead supposed to reside in Anglican, Methodist, Presbyterian and Roman Catholic white-led mission churches. But, living side by side with Zionist congregations in Zululand as a missionary, Sundkler's curiosity about this popular black religiosity led him to take Zionists more seriously. He argued that while the African Christians he observed in 1940s Zululand had discarded many aspects of the old 'pagan'

\footnotetext{
${ }^{1}$ Martin West, Bishops and Prophets in a Black City: African Independent Churches in Soweto (London, 1975$), 2$.

${ }^{2}$ Retief Muller, African Pilgrimage: Ritual Travel in South Africa's Christianity of Zion (Surrey, 2011)

${ }^{3}$ James Kiernan, 'The Work of Zion: An Analysis of an African Zionist Ritual', Africa: Journal of the International African Institute 55, 3 (1976), 340-355.

${ }^{4}$ Bengt Sundkler, Bantu Prophets in South Africa (London, 1948).
} 
order, in Zionist churches there was still a strong emphasis on pre-Christian ritual. ${ }^{5}$ Sundkler thus drew a now-famous chart comparing how old religious rituals - the 'surviving forms of Zulu culture' - found 'new expressions in Zionist churches'. ${ }^{6}$ He concluded that Zionist church rituals such as healing, prophecy, and baptism were evidence of the old religion with merely a Christian gloss upon it, 'new wine in old wineskins'. 'Zionism was a means for mid-twentieth century Africans - amidst apartheid and economic and territorial dispossession - to give 'a more honored place... to the religious and cultural heritage of the Zulus'.

While Sundkler's early analysis was highly ambivalent about Zionists' orthodoxy (he was after all a 1940s Lutheran missionary), subsequent scholarship - including a later edition of Sundkler's own Bantu Prophets ${ }^{9}$ - were far more celebratory of Zionism's status as an indigenous African Christian movement. Scholars such as Jean Comaroff, amongst many others, seized upon Zionists as examples of the resilience of African religiosity against a 'foreign' European Christianity. ${ }^{10}$ Rather than being understood in the context of an evangelical Christian tradition long concerned with bodily healing therapies, Zionists' healing rituals were instead interpreted as remnants of indigenous cosmologies, evidence of Africans' ability to appropriate western Christianity, to remake it in the mould of so-called traditional African religious practices, and to thereby mediate the alienating effect of colonial capitalism. ${ }^{11}$

What many of these studies neglected, however, is that the origins of Zionism in South Africa this supposedly most 'African' of all religious movements in Southern Africa - lay far outside of the region. Rather than a genuinely local growth, Zionism, introduced to South Africa in the 1890s, was in fact the product of a white North American missionary organization known as the Christian Catholic Apostolic Church in Zion. In this respect, Sundkler's later 1976 study Zulu

${ }^{5}$ Sundkler, Bantu Prophets, 181.

${ }^{6}$ Sundkler, Bantu Prophets, 262-263.

${ }^{7}$ Sundkler, Bantu Prophets, 278.

${ }^{8}$ Sundkler, Bantu Prophets, 17.

${ }^{9}$ Bengt Sundkler, Bantu Prophets in South Africa, $2^{\text {nd }}$ Edition (Oxford: African International Institute, 1961).

${ }^{10}$ Terence Ranger, 'Connexions between Primary Resistance Movements and Modern Mass Nationalism', Journal of African History 9, 3/4 (1968), 437-453.

${ }^{11}$ Jean Comaroff, Body of Power, Spirit of Resistance: The Culture and History of a South African People (Chicago, 1985); James Kiernan, 'Saltwater and Ashes: Instruments of Curing Among Some Zulu Zionists', Journal of Religion in Africa 9 (1978): 27-32; Allan Anderson, 'The Lekganyanes and Prophecy in the Zion Christian Church', Journal of Religion in Africa 29, 3(1999), 285-312, at 308; Allan Anderson, Moya: The Holy Spirit in an African Context (Pretoria, 1991); Retief Muller, African Pilgrimage: Ritual Travel in South Africa's Christianity in South Africa's Christianity of Zion (Aldershot: Ashgate, 2011). 
Zion and Some Swazi Zionists offered an important qualification to the general trend. ${ }^{12}$ In Zulu Zion, Sundkler nuanced the by-then usual depiction of Zionism in Southern Africa as an exclusively black phenomenon by demonstrating the importance of local white evangelical culture to its early history, detailing the extensive involvement of like-minded whites in propagating Zionism across the districts of the Transvaal and Orange Free State. ${ }^{13}$ Sundkler thus showed us that the early beginnings of black Zion were not as 'exclusively African as one might like to believe. The first decade...echoes with the...relationship between White commitment and an emerging Black charismatic community.' ${ }^{14}$

But while Sundkler demonstrated that the earliest decade of the local movement was considerably inter-racial, he nonetheless left largely unexplored the exact character of the internationalist resources both black and white South Africans were receiving from North America. While detailed in his analysis of why white evangelicals in South Africa joined the movement, he spent little time situating the development of Zionism in Southern Africa as an outgrowth of a Midwestern faith healing movement. And although Sundkler showed us that both blacks and whites responded with alacrity to Zionism, he did not explain why and how this worldwide Protestant phenomenon resonated so profoundly on both sides of the Atlantic. For even although within a few decades many - but not all - both black and white Zionists had separated from the original North American denomination to found their own independent congregations, a large number of these autonomous groups nonetheless sustained intensive contact with the North American, white-led mother church throughout the twentieth century. As I shall argue in this piece, the influence of turn-of-the-century Midwestern Zionism - a popular working-class religiosity focused on bodily perfection and overall self-improvement - was longenduring in Southern Africa, with its influence felt even after the departure of American missionaries. But most scholars - including Sundkler - have depicted the contribution of North Americans to African Zionism as merely a transitory phase of limited influence. ${ }^{15}$ In this way, Zionism's origins as a phenomenon arising as the result of complex collaborations and alliances

\footnotetext{
${ }^{12}$ Bengt Sundkler, Zulu Zion and Some Swazi Zionists (Oxford: Oxford University Press, 1976)

${ }^{13}$ See Sundkler, Zulu Zion, 13-67

${ }^{14}$ Sundkler, Zulu Zion, 66.

15 Although for two qualifications, see David Maxwell, 'Historicizing Christian Independency: The Southern African Pentecostal Movement, c. 1908-1960', The Journal of African History 40, 2 (1999), 243-264; Joel Cabrita, 'People of Adam: Divine Healing and Racial Cosmopolitanism in Transvaal, South Africa', Comparative Studies in Society and History, 57, 2 (2015), 1-36.
} 
between blacks and white Zionists in South Africa, and white Zionists in the USA, are obscured. $^{16}$

The reasons for scholars' focus on Zionism as a nativist movement are not hard to find. Shaped by the wave of political independence sweeping the continent, and the corresponding search for African identities, post-colonial scholars of the 1960s seized upon the thousands of black-led, healing-focused Zionist churches as evidence of African resistance to a 'white' Christianity, a genuinely 'African' translation of the gospel amidst politically adverse circumstances. ${ }^{17}$ Even Sundkler in 1976 - more cognizant than most of the contribution of local whites to the movement - expressed wariness at flagging up the importance of non-African elements to Zionism at that particular historical juncture: 'it would seem unfortunate, perhaps, not to say unwise, at this time of Black Power and Black Theology to try to argue such a case, as though even this purely and gloriously Black movement of the Spirit somehow originated with a few Whites. ${ }^{18}$ And not only did missionaries appear to many liberal academics and observers to be profoundly implicated in the machinations of colonialism, but a growing attention to the profound demographic shift of Christianity from the North and the East to the Global South was also transforming scholarly models for the study of Christianity outside of the West. Rather than a focus upon the activity of Western missionary societies in Africa, scholars were now disposed to view faith communities as unique centres of Christianity in their own right, developed with little or even no attention to traditional missionary-sending centres.

In particular, Lamin Sanneh's influential work on the 'translatable' Gospel informed how indigenous non-Western churches such as the Zionists in South Africa were viewed. In his Translating the Message, Sanneh described how as Christianity expanded into new environment beyond its Middle Eastern milieu it faced new challenges as a minority religion within nonChristian societies. ${ }^{19}$ The key to Christianity's subsequent success was its 'translatability'. According to Sanneh, this was Christianity's intrinsic, engrained capacity to not remain enshrined within a single language or cultural system, but rather to adapt to local cultural and

\footnotetext{
${ }^{16}$ Muller, African Pilgrimage, 11-13.

${ }^{17}$ Ranger, 'Modern Mass Nationalism', 437; Harold Turner, 'A Typology for African Religious Movements', Journal of Religion in Africa 1, 1 (1967), 1-32.

${ }^{18}$ Sundkler, Zulu Zion, 14. For evidence of similar hesitations on the part of Sundkler in proffering evidence of white European or American contributions to African Zion, also see Zulu Zion, 57 fn. 56.

${ }^{19}$ Lamin Sanneh, Translating the Message: The Missionary Impact on Culture (Maryknoll, N.Y., 1989).
} 
linguistic contexts. Thus Pentecost, that singular occasion in Jerusalem when each person heard what was being spoken 'in his own tongue', reversed the disorderly confusion of Babel. Rather than humanity's different cultures resulting merely in incomprehensible fragmentation, Sanneh proposed that Christianity grafted itself onto a wide range of different cultures and languages; human cultural difference was not the seed of disorder, but rather the bearer of divine revelation. $^{20}$

The implications of Sanneh and others' approach for the study of Christian movements outside of the Western world has been profound, predisposing scholars to focus on the local, regional characteristics of Christianity. Thus Sanneh has also argued against the term 'Global Christianity' on the grounds that it obscures the local particularity of the multiple Christianities of varying cultural contexts, wrongly foregrounding a homogenizing, European form of Christianity. ${ }^{21}$ According to Sanneh, it is 'World Christianity', in contrast to 'Global Christianity', in which the voices of Global South Christians speak freely for themselves. ${ }^{22}$ Guided by this particularist impulses exemplified in Sanneh and others' scholarship, the topographical 'map' of non-Western Christianity now tends to be highly fragmented, comprised of multiple local Christianities studding the globe, but rarely interacting with each other, nor with traditional missionary-sending centres, and possessing little consciousness of belonging to a single religious community. ${ }^{23}$ These scholars study how Christians translated a universal faith into local concerns, rather than how a universal faith knits together a range of local believers. ${ }^{24}$ And so, in emphasizing the autonomy of local Christianities, this scholarship perhaps runs the risk of neglecting the other side of the story: that local Christians across the world have highly prized contact with Christians in the so-called Global North, as well as sustained exchanges with believers in other parts of the southern hemisphere, choosing to stress not only their regional credentials, but also their universalist affiliations.

Furthermore, in the case of Zionism, the model of indigeneity may obscure more than it reveals. For one, it imbues 'Africanness' with an overly exaggerated explanatory power in accounting for

\footnotetext{
${ }^{20}$ The missionary scholar Andrew Walls made a similar argument in The Missionary Movement in Christian History (Edinburgh, 1996)

${ }^{21}$ Lamin Sanneh, Whose Religion is Christianity? The Gospel Beyond the West (Cambridge, 2003), 35

${ }^{22}$ Sanneh, Whose Religion Is Christianity?, 22

${ }^{23}$ E.g. Charles Farhardian, ed., Introducing World Christianity (Oxford, 2012).

${ }^{24}$ Dale T. Irvin, "World Christianity: An Introduction,"' Journal of World Christianity 1, 1 (2008): 1-2.
} 
the popularity of Zionism in South Africa. In seeking to emphasize local agency, exponents of this approach have placed too great an emphasis on black South Africans' reliance upon tropes of ethnicity and local culture; black South Africans, as much as any ethnic constituency in history, have also used resources far beyond their immediate cultural horizons. A rich new body of transnational history - locating South African within currents of global history - is pertinent in this regard. ${ }^{25}$ Furthermore, Christianity's transformative power to cut across culture as well as be translated within culture must be accounted for. Following the recent approach of the Anthropology of Christianity school, exemplified by the work of Joel Robbins and others, it is evident that believers across the globe have chosen to stress that fidelity to Christ does not necessarily baptize their existing culture and language but rather enacts a radical break with pasts frequently characterized by converts as degenerate, corrupt and sinful. ${ }^{26}$

Following in this revisionary spirit, then, and building upon Sundkler's own path-breaking contribution from the 1970s, this piece argues the time is ripe for a reappraisal of Zionism as a moment in transatlantic history and international Protestantism, rather than as a nativistic Christian appropriation. The following eschews the usual portrayal of Zionism as an indigenous Southern African movement. Instead, the origins of Zionism are situated in the North American Divine Healing movement of the late nineteenth century, demonstrating that the Christian Catholic Apostolic Church in Zion was a unique product of the rapidly industrializing Midwestern metropolis of Chicago. It was particularly the universalist promise of the new Zion church - its self-proclaimed aspiration to remake all humanity into a new redeemed race, characterized by healthy bodies - that appealed to a recently urbanized, working-class, largely immigrant Northern European Chicago-based population eager to assimilate to the New World. The article then shows how the rapid transmission of these universalist beliefs to black South Africans in the farmlands of the early twentieth-century Transvaal was not, after all, so great a jump. Dispossessed by rapid industrialization and marginalized by racial segregation (these were intertwined processes), black farmers embraced Zionism's egalitarian healing techniques as a means of asserting their equality with like-minded believers across the world. Attending to this

\footnotetext{
${ }^{25}$ See for example, James T. Campbell, Songs of Zion: The African Methodist Episcopal Church in the United State and South Africa (Oxford, 1995); Isabel Hofmeyr, The Portable Bunyan: A Transnational History of the Pilgrim's Progress (Princeton, 2004); Robert Vinson, The Americans are Coming! Dreams of African American Liberation in Segregationist South Africa (Athens, OH, 2012).

${ }^{26}$ Fenella Cannell, ed., The Anthropology of Christianity (Durham, 2006).
} 
comparative element allows us to move away from isolated regional histories of Christianity in South Africa and the USA, and to instead consider Protestantism in Africa as the fruit of lively transatlantic exchanges (and conflicts) throughout the late modern period.

\section{Zionism in the American Midwest}

John Alexander Dowie was the Divine Healing movement's most famous figure. Born in Edinburgh in 1847 to a tailor father, in 1860 the Dowies immigrated to South Australia, part of the wave of working-class Scottish emigration of this period. ${ }^{27}$ After a return to Edinburgh to study theology, Dowie was ordained pastor of an Australian Congregationalist church. Through periodicals and international revivalist networks, Dowie became an advocate of Divine Healing. This was a quite mainstream phenomenon within Protestantism, reflecting both the period's Methodist-derived perfectionistic confidence (Christ could redeem the body as well as the soul), as well as its intense interest in bodily health against a backdrop of industrialization and urbanization, exemplified by the popularity of rival therapies such as hydrotherapy, homeopathy and magnetism. By the 1860s and 1870s, Divine Healing associations and groups were found in a number of European capitals and in cities along the East Coast of the United States, as well as in the rapidly emerging Australian and Canadian metropolises of the Anglo world. ${ }^{28}$ Deeply impressed by its powerful spiritual techniques, by the late 1870s, Dowie had fallen out with the Congregationalist establishment in Australia and had founded his own independent Divine Healing Association in Melbourne. ${ }^{29}$

From its early beginnings in Australia, Dowie's experiments with Divine Healing were shaped by a broader set of Protestant concerns regarding a new swathe of largely working-class citydwellers. Melbourne, as with other major Australian cities of the period, was the site of intense anxiety on part of Protestant activists regarding the demoralizing and enervating effects of industrialization on this new urban working-class. ${ }^{30}$ While the work of many Protestant reform

\footnotetext{
${ }^{27}$ Eric Richards, 'Migrations: The Career of British White Australia', in Deryck Schreuder (ed.), Australia's Empire, (Oxford: Oxford University Press, 2008), 168.

${ }^{28}$ Heather D. Curtis, Faith in the Great Physician: Suffering and Divine Healing in American Culture, 1860-1900 (Baltimore: Johns Hopkins University Press, 2007)

${ }^{29}$ The Christian Alliance, February 1888.

${ }^{30}$ Graeme Davison et al (eds.), The Outcasts of Melbourne: Essays in Social History (Allen \& Unwin, 1985); A.J.C. Mayne, Fever, Squalor and Vice: Sanitation and Social Policy in Victorian Sydney (New York: University of Queensland Press, 1982
} 
groups sought to 'uplift' the urban poor while leaning upon an elitist rhetoric of working-class degeneracy, other religious movements-including the newly founded Salvation Army - emerged as more populist movements. These were instances of evangelical piety appropriated by the city's working classes for their own ends, and in ways the Protestant establishment - including Dowie's own Congregationalist church - often deeply disapproved of due to their exuberant public piety. ${ }^{31}$ After resigning from the Congregationalists, Dowie briefly worked with the Salvation Army. ${ }^{32}$ Its populist influence upon him was clear; in forming his new Association, Dowie proclaimed Divine Healing a movement for the working people of the city, and in angry written and spoken polemic, frequently pitted it against the ineffectual interventions of the Protestant establishment. For in sharp contrast to entrenched Protestant tropes of working-class degeneracy and 'poor-shaming', his new Divine Healing services in Melbourne offered working men and women the promise of full and permanent bodily perfection, and proclaimed spiritual power was available to them at merely the request of a prayer. ${ }^{33}$ Many for whom Dowie prayed in his regular services in the working-class suburbs of Fitzroy and Collingwood told of feeling extraordinary bodily jolts during the experience of laying-on of hands: a 'shock as the Holy Spirit's power' passed through them, as one devotee recounted. ${ }^{34}$ Some claimed that they experienced healing instantaneously, and as a consequence, found their lives greatly transformed for the better, including with economic benefits; a Mrs Parker of Napier Street in Fitzroy, a tailoress who relied upon her sight for her living, recalled Dowie prayed for a 'running cancer' in her eye, and that upon his touch it burst and 'poured' out. ${ }^{35}$

Following these formative years in urban Australia, Dowie and his family travelled to California where he preached and healed in missions along the Pacific Coast. By 1893, Dowie - as did many others - travelled to Chicago's World Fair, holding healing meetings in a rickety wooden

\footnotetext{
${ }^{31}$ Diana Winston, Red Hot and Righteous: The Urban Religion of the Salvation Army (Cambridge, MA.: Harvard University Press, 1999);

32 J. Hein, 'A Crisis of Leadership: John Alexander Dowie and the Salvation Army in South Australia', Journal of the Historical Society of South Australia, 39 (2011), 65-77

${ }^{33}$ See Joel Cabrita, Empire of Healing: South Africa, the United States and the Transatlantic Zionist Movement (Cambridge, MA.: Harvard University Press, forthcoming)

${ }^{34}$ John Alexander Dowie, Record of the Fifth Annual Commemoration of the Rev. John Alexander Dowie and Mrs Dowie's Ministry of Healing Through Faith in Jesus, Held in the Free Christian Tabernacle, Fitzroy, Melbourne, Lord's Day December $4^{\text {th }}$ and Monday December $5^{\text {th }}, 1887$. Containing Testimonies from Those Healed, and Ebenezer Address (Melbourne, 1888), 45.

${ }^{35}$ Dowie, Ministry of Healing Through Faith, 18; W.E. Boardman, Record of the International Conference on Divine Healing and True Holiness, Held at the Agricultural Hall (St Mary's Agricultural Hall, Islington) (London, 1885), 69
} 
tabernacle on the Fair's perimeters. Riding the wave of subsequent publicity, in 1896 Dowie founded his own Chicago-based church, the Christian Catholic Apostolic Church in Zion. In addition to divine healing, what might be called universalism was a key tenet of the church. While the inclusion of 'Apostolic' in the church's name reflected his preoccupation with restoring primitive Christianity (including the practice of healing through faith), 'Catholic' indicated Dowie's older commitment (discernable even in his Australian days) to an inclusivist organization that cut across secular markers of class, rank, denomination and even, as we shall see, ethnicity. In Chicago, Dowie opened several healing homes which were heavily patronized by women. He started a periodical, Leaves of Healing, which broadcast his healings by imitating techniques of popular broadsheets - eye-grabbing headlines, compelling testimonies and dramatic photographs. Soon, branches of the 'Zionite' church sprung up around the Midwest and the entire country.

Chicago in the 1890s epitomized the dramatic economic and social changes catalyzed by America's industrializing economy. By 1890, Chicago was the United States' second city, subordinate only to New York in economic power and size. ${ }^{36}$ Chicago's unique position lay in its role as broker between Eastern cities and the natural resource rich Midwest; for example, its meat and lumber factories and steel mills, and its monopoly of railroads linking the East Coast to the West. ${ }^{37}$ The worldwide Divine Healing movement especially flourished in locations such as Chicago, a premier example of the large industrializing cities of the late nineteenth-century Atlantic World. Although occasion for self-congratulation in booster accounts, the rapid pace of urban social change in these cities also caused much anxious social commentary. Worries were voiced in terms of the poor health precipitated by industrialization and urbanization. In North American as well as Australian cities, commentators worried that industrialization undermined modern peoples' health, resulting in decadent manhood and poor racial health. ${ }^{38}$ Neurasthenia was considered a principal nervous ailment linked to industrialization, draining men of their vigor and lowering the birth rate. ${ }^{39}$ New occupational diseases abounded, including lung diseases

\footnotetext{
${ }^{36}$ Thekla Ellen Joiner, Sin in the City: Chicago and Revivalism, 180-1920 (Columbia, M.O., 2007), 21.

${ }^{37}$ Dominic A. Pacyga, Polish Immigrants and Industrial Chicago: Workers on the South Side, 1880-1920 (Columbus, O.H., 1991), 24; William Cronon, Nature's Metropolis: Chicago and the Great West (New York, 1991)

${ }^{38}$ Clifford Putney, Muscular Christianity: Manhood and Sports in Protestant America, 1880-1920 (Cambridge, Mass., 2001), 4.

${ }^{39}$ Robert Fuller, Alternative Medicine and American Religious Life (Oxford, 1989), 63; Heather D. Curtis, Faith in the Great Physician: Suffering and Divine Healing in American Culture (Baltimore, 2007), 104.
} 
from industrial dust and damaged spines through long hours over new machinery. ${ }^{40}$ Housing for the new urban laboring classes was cramped and insanitary. Evangelical Protestant urban reform movements such as the YMCA and the Salvation Army focused on improving public and personal health in a swathe of these Anglo world cities, including tightening temperance laws and advocating for reform in slums housing. Stressing temperance, Divine Healing advocates also emphasized the intertwined importance of a sanctified soul and a healthy body, especially in environments dubbed 'unhealthy' and morally corrupting as Chicago was imagined to be. ${ }^{41}$

But in Chicago Dowie also encountered a further phenomenon of urban industrialization, one he had not experienced in Melbourne, and which was unparalleled in any other global city save New York: an extraordinarily polygot and ethnically heterogeneous working-class population. Chicago's explosive growth had largely been fueled by migrant labour from outside of the United States. By 1890, 78\% of the city’s population was of foreign, largely European, parentage, with many more immigrants arriving yearly. ${ }^{42}$ Germans made up the largest immigrant group, with industrialization and commercialized agriculture in Germany leading to mass immigration to the New World. ${ }^{43}$ Over two-thirds thirds of Chicago's German community living in working-class households, engaged in traditional crafts such as furniture-making as well as absorbed by the city's new factories. ${ }^{44}$ Many who flocked to Dowie's new Zion Tabernacle were drawn from precisely this newly-arrived, working class constituency eager for social and economic mobility and self-improvement in the New World. Fred Trampsich, a German-born, self-professed 'low man, a drinker, a smoker, a chewer, a filthy man' was one of the thousands who by the early 1890s had heard of this 'wunder doctor at the World Fair'. He visited Zion's Tabernacle, and 'Dr Dowie laid hands of me, my disease passed away...today I can say I'm a healthy man. ${ }^{45}$ Another example was George Wiedeman, a second-generation German immigrant who worked his way to Chicago from New York to become a painter at the World Fair. While there, he heard Dowie preach and was so impressed that he boarded with a family

\footnotetext{
${ }^{40}$ Bruce Haley, The Healthy Body and Victorian Culture (Cambridge, Mass.: Harvard University Press, 1978 ), 12. Putney, Muscular Christianity, 4.

${ }^{41}$ Curtis, Faith in the Great Physician, 175.

${ }^{42}$ Bessie Louise Pierce, A History of Chicago (New York, 1937), 22.

${ }^{43}$ John Bodnar, The Transplanted: A History of Immigrants in Urban America (Bloomington: Indiana University Press, 1985), 14.

${ }^{44}$ Hartmut Keil and John B. Jentz, eds., German Workers in Chicago: A Documentary History of Working-Class Culture from 1850 to World War I (Urbana, 1988), 1.

${ }^{45}$ Leaves of Healing, Vol. 2, No. 45, 4 September 1896
} 
near the Tabernacle so he could regularly attend services. ${ }^{46}$ Swedes, Norwegians and Czechs were also well-represented among those who attended Dowie's Tabernacle services. For example, there was Karin Lindquist, a Swedish-born domestic servant in Chicago, who read about Zion Tabernacle in the city's newspaper Chicago Inter Ocean and attended Dowie's healing services. She was a sufferer from lumbago, and 'what a relief to hear that God could heal us...the first time you [Dowie] laid hands on me, the pain ceased. ${ }^{47}$

What drew this group of newly industrialized, working class immigrants to Dowie's church? Divine Healing was key to the church's popularity in late nineteenth-century Chicago. The church's rhetoric of bodily perfection undoubtedly resonated with these new urbanites who frequently experienced their environments as deeply physically degrading. While factories carried grave occupational dangers, it was estimated that half of Chicago's children died before five due to poor sanitation and overcrowding. ${ }^{48}$ Dowie's promise of healing resonated with a population that - as in Melbourne - lived in the most squalid areas of the city, and were simultaneously unlikely to use the expensive services of private physicians, many of whom were in any case regarded with great mistrust in this still uncertain period of medical advance.

Moreover, in the context of a lively milieu of religious debate in the city, the perfectionistic underpinnings of Divine Healing were far from new to this immigrant constituency. Despite the fact that immigrant Lutheran and Catholic churches were highly influential, many religious organizations in the Midwest of the late nineteenth century were nonetheless riven with debate over newer and still controversial forms of evangelical spirituality. ${ }^{49}$ This was especially true of Swedish Lutherans who were still reverberating from the evangelical awakenings of the 1850s, where 'Meetingsmen' departed from the set liturgy of the National Church of Sweden (Lutheran) to focus on the transformative effect of a private, highly pious conversion. ${ }^{50}$ Once transplanted to Chicago many of this evangelical working-class group joined organizations such as the Zionist

\footnotetext{
${ }^{46}$ Zion Historical Society Magazine, Series 4, 1971, 'Who's Who in Zion'

${ }^{47}$ Leaves of Healing, Vol. XIV, No. 19, 27 February 1904

${ }^{48}$ Pierce, History of Chicago, 55; Stanley Buder, Pullman: An Experiment in Industrial Order and Community Planning, 1880-1930 (Oxford: Oxford University Press, 1967), 34.

${ }^{49}$ Bodnar, The Transplanted, 144-168

${ }^{50}$ Karl A. Olsson, 'Dwight L. Moody and some Chicago Swedes' in Philip J. Anderson and Dag Blanck, eds., Swedish-American Life in Chicago: Cultural and Urban Aspects of an Immigrant People (Uppsala, 1992$), 323$.
} 
church, whose emphasis on bodily perfectionism meshed well with their interest in personal conversion and transformation. ${ }^{51}$

In addition to tapping into a European-American constituency that already - amongst sections of itself - favored an evangelical, personal spirituality, Dowie's church was also perceived by his followers as highly sympathetic to precisely their own immigrant constituency. Dowie's marveling appreciation of Chicago's diversity was frequently voiced in the Leaves' editorials: he repeatedly lauded that 'we are living in a city where all the nations of the earth are assembled. ${ }^{52}$ Ethnic heterogeneity came to be interpreted via a biblical grammar that celebrated Christ's impending sovereignty over the entire world; Dowie and his followers deeply felt the spiritual value of a pan-ethnic fellowship where 'the nations would be assembled together' in glorious foretaste of Christ's coming Kingdom. ${ }^{53}$ Dowie and this first generation of 'Zionites' saw this cosmopolitan community a dramatic illustration of the fraternity of Christians, imperfectly realized in the present-day but to be fulfilled at the end of times. A much-quoted saying of Dowie's was thus that 'neither race, nor colour, nor education, nor position, nor wealth can be a barrier to fellowship, for our Lord said, 'One is your master and all ye are Brethren.' There are no aliens among Christians. ${ }^{54}$ Echoing the inclusivist rhetoric of his Melbourne days, Dowie was explicit in his sermons to the Chicago faithful that all were welcome in the church, regardless of ethnicity or nationality. This was especially powerful a context where workingclass immigrants often reported feeling stigmatized by the city's English-speaking Anglo Protestant establishment. The Chicago German-language newspaper Fackel published a satirical account of a devout working man named 'Zachary Godloving' who was refused entrance to the churches of the city's Anglo middle and upper classes on account of his heavy accent and shabby clothing. ${ }^{55}$ Dowie, by contrast, proclaimed himself as a church for the immigrant, no matter how down-and-out, booming from the pulpit of his huge new Tabernacle on Michigan Avenue that "while many of us here are called "foreigners" in this country, if you are a Christian, you are not a foreigner in the Church of God [applause]. There is one place you won't be called a stranger or

\footnotetext{
${ }^{51}$ Olsson, 'Dwight L. Moody', 307-323; Lillian Taiz, ‘Applying the Devil's Works in a Holy Cause: Working Class Popular Culture and the Salvation Army in the United States, 1879-1900', Religion and American Culture 7, 2 (1997), 199.

${ }^{52}$ Leaves of Healing, Vol. 1, No. 39, 5 July 1895

${ }^{53}$ Ibid.

${ }^{54}$ Leaves of Healing, Vol. 1, No. 30, 26 April 1895

${ }^{55}$ E.g. 'Sunday Observations' (Fackel, 14 September 1884) in Keil and Jentz, German Workers in Chicago, 357.
} 
a foreigner, and that will be the Christian Catholic Church.... we do not want to hear 'foreigner' applies to brethren or any such nonsense. ${ }^{56}$

In voicing such cosmopolitan sentiments, Dowie was tapping into a vein of thought already existent amongst Chicago's immigrant population. This was a sentiment that aspired to transcend ethnic and national differences by joining forces in a new common identity forged in the New World. While Old World resources were skillfully deployed in industrialized settings (language and culture could certainly be powerful identity-building resources), many within immigrant communities simultaneously aspired to think of themselves in ways antithetical to narrower ethnic self-identification, seeking the elusive goal of 'Americanizing'. Trade unions of the period were important venues for such projects of ethnic cosmopolitanism; one Lithuanian packinghouse worker commented in 1904 that joining the Union 'is giving me [a chance]to enjoy life like an American... it is combining all the nationalities, the night I joined the Cattle Butchers' Union, I was led into the room by a Negro member, with me were Bohemians, Germans, Poles, and the President is an Irishman who spoke to us in English. ${ }^{57}$ Echoing the internationalism of trade unions, the Christian Catholic Apostolic Church in Zion offered its polyglot membership a platform for pan-ethnic fellowship, while simultaneously catering to cherished ethnic and linguistic communal identities. Services were regularly translated into multiple languages, and special missions were held for different nationality groups in areas of the city where they lived. ${ }^{58}$ Leaves of Healing was produced in a German version by $1895 .{ }^{59}$ Soon editions of Leaves in Swedish, Norwegian, Dutch and French were out, translated by devout members in their own time and at no cost. ${ }^{60}$

The church's vision of a reformed industrial society, characterized by good health, temperance and the harmonious coexistence of nationalities, culminated in the purchase in 1900 of land forty miles north of Chicago. Here Dowie and church members founded Zion City, a town designed along biblical lines, which at its height in 1904 had 6000 residents. ${ }^{61}$ Many Zionists - the press scathingly called them 'Dowietes' - were Northern European first and second-generation

\footnotetext{
${ }^{56}$ Leaves of Healing, Vol. 2, No. 17, 31 January 1896

57 James R. Barrett, Work and Community in the Jungle: Chicago's Packinghouse Workers, 1894-1922 (Urbana, 1987), 141.

${ }^{58}$ Leaves of Healing, Vol. 4, No. 27, 30 April 1898

${ }^{59}$ Leaves of Healing, Vol. 2, No. 4, 1 November 1895

${ }^{60}$ Leaves of Healing Vol. 2, No. 37, 3 July 1896; Vol. 3, No. 4, 20 November 1896; Vol. IV, No. 26, 21 April 1900;

${ }^{61}$ Zion Banner, 3 May 1904.
} 
immigrants from Chicago, while some relocated to Zion from rural states like Colorado, Nebraska and Minnesota. All were attracted by Zion's utopian vision of an ideal environment for immigrant working people prizing godliness, health and the promise of non-discrimination on the basis of nationality or language. ${ }^{62}$ To offer residents sustainable employment, Dowie imported a lace factory piece-by-piece from England and fifty skilled workers from Nottingham. ${ }^{63}$ Unions were banned, but eight-hour working days were mandated and working conditions tightly regulated: Dowie's 'aim [was] a population of godly people who shall work together for something more than dollars. ${ }^{64}$ Dowie employed a civil engineer who, inspired by Ebenezer Howard's Garden City movement, located industry at Zion's periphery, ensuring a green, tranquil centre with boulevards and leafy avenues. ${ }^{65}$ Residential lots were large, and made no discrimination in size between poorer income and wealthier areas. Doctors, chemists, alcohol, tobacco and gambling were all prohibited.

Its organizers and residents made much of Zion City's cosmopolitanism, a sign of the restoration of the Kingdom of God where the 'nations' mingled freely and harmoniously. Five years after the city's founding, Dowie boasted that 'Zion City, ethnologically, is a miniature representation of the world....the citizens of our city represent over 80 nationalities. ${ }^{66}$ The church was especially proud of the 200-strong community of African-Americans in Zion City, identifying blacks with the biblical 'race of Ethiopians'. Zion City's incorporation of 'Ethiopians' was therefore lauded in booster accounts as a foretaste of Christian victory: 'there is victory all along the line. Prophecy is being fulfilled. Ethiopia is "hastening to stretch out her hands unto God.",67 The view that racial difference should be subordinate to Christian unity led Dowie to controversially argue for 'miscegenation', a bio-spiritual discipline that - like Divine Healing rehabilitated degenerate bodies. ${ }^{68}$ And if Zion City was a home for the world's races, then Dowie was equally adamant that Zionist teachings should fan out across the world and draw all of humanity into its orbit. In this spirit, after 1900, the church sent missionaries to Australia, New Zealand, China, Japan, and in 1904, to the Transvaal in the territory that would be known as

\footnotetext{
${ }^{62}$ Ibid, 175-176.

${ }^{63}$ Jan Jansen, Battle for the Garden City (no place, 2011), 63.

${ }^{64}$ Leaves of Healing, January 221901.

${ }^{65}$ Jansen, Garden City.

${ }^{66}$ Leaves of Healing, Vol. XVII, No. 5, 24 May 1905

${ }^{67}$ Ibid.

${ }^{68}$ Zion Banner, 1 September 1905.
} 
South Africa, newly at peace after a devastating three-year war between Briton and Boer. Politically and economically speaking, black Africans were the principal casualties of the war's after-effects, and it was precisely to this marginalized constituency that Zionism would come to speak to most powerfully in the following decades.

\section{Zionism in South Africa}

By the end of the nineteenth century, the worldwide dissemination of Leaves of Healing meant that Dowie's church already had a vibrant following amongst a small community of whites both Boers and Britons - in South Africa. In 1904, two Midwestern missionaries from Zion City - a married couple, Daniel and Emma Bryant - arrived in Johannesburg, South Africa, recently ordained Evangelist and Elder (the latter the highest rank a woman could hold). ${ }^{69}$ Commissioned by Dowie to extend Divine Healing to the region's African population, the Bryants made contact with two local white members of Dowie's church already engaged in missionary work with black communities - Pieter le Roux a former Dutch Reformed cleric, and Edgar Mahon an-ex Salvation Army captain. Le Roux was the former missionary to the Zulu for the Dutch Reformed Church in the Transvaal district of Wakkerstroom, a region dominated by stock-farming, maize and tobacco production. Despite the evangelical leanings of the Dutch Reformed Church in this period, and the fact that some in its upper echelons practiced Divine Healing (including the highly respected theologian and minister, Andrew Murray ${ }^{70}$ ), its officials had 'serious objections' to Le Roux disseminating these teachings amongst Africans, ${ }^{71}$ worrying that Divine Healing would appeal primarily as an efficacious technology, rather than as part and parcel of the Christian Gospel, thereby 'distracting [Africans'] attention from more essential things. ${ }^{72}$ But Le Roux was unable to comply with a racial demarcation of Divine Healing's blessings. As one who could 'personally bear witness of this 'happy tiding' he avowed he could not 'remain silent about this any longer. ${ }^{73}$ In 1903, Le Roux enlisted as a member of Dowie's church, ordained by Dowie - via postal communication - as a Zion missionary to his black former Dutch Reformed congregants. Edgan Mahon was another local white figure who found established Protestant

\footnotetext{
${ }^{69}$ Christ Community Church Archives Zion City, Illinois, John Dowie to Daniel Bryant, 'General Instructions Given to Overseer Daniel Bryant', November 5 1903, 12.

${ }^{70}$ Johann Du Plessis, The Life of Andrew Murray in South Africa (London: Marshall Bros, 1920), 230-231.

${ }^{71}$ Apostolic Faith Mission Archives Johannesburg (hereafter AFM), Pieter Le Roux Correspondence, Pieter Le Roux to Revs. Kriel, Marais, Rossouw, Meiring, Bosman, 12 November 1898

${ }_{72}$ AFM Archives, Pieter Le Roux Correspondence, Rev. Andrew Murray to Pieter Le Roux, 29 November 1898

${ }^{73}$ AFM Archives, Pieter Le Roux Correspondence, Pieter Le Roux to Rev. Andrew Murray, 12 November 1898.
} 
churches of the day would not support divine healing, particularly amongst Africans. The Irish Mahon had joined the Salvation Army in the working-class suburb of Fordsburg in early gold rush Johannesburg, and as an adult became a Salvationist missionary. ${ }^{74}$ During a bout of lung illness, Mahon read Dowie's literature, and greatly inspired, began to teach divine healing to the Africans he was ministering to. But the local Salvation Army opposed this (perhaps also due to a particular dislike of Dowie himself, who had since fallen out with Army leadership ${ }^{75}$ ), leading to Mahon's resignation. Mahon became an independent missionary in the Orange Free State, where he and his family were housed upon the farms of sympathetic evangelicals, ${ }^{76}$ charged with preaching to Africans on the surrounding farms, as well as free to practice supplicating God through prayer for bodily healing. ${ }^{77}$

In South Africa, as in the United States, Zion's cosmopolitan ethos greatly appealed to both whites and blacks. Individuals such as Le Roux and Mahon were part of a group of several hundred white members of Dowie's church in early twentieth-century South Africa. Divine Healing appears to have particularly taken off during the South African War; copies of Leaves were disseminated amongst both Boer and British soldiers (even reaching as far as Boer POW camps in Ceylon and India), and its tenets were preached in evangelistic meetings in camps, hospitals and mess rooms. ${ }^{78}$ While a gospel of physical uplift undoubtedly resonated during difficult war-time conditions, amidst the fierce conflict between the two white 'races', the church's purposively internationalist message also came to the fore. Newly-converted Zionists asserted it was their duty to assert kinship with enemy combatants. John Taylor, a clerk in a law firm in Pietermaritzburg, enlisted as a military chaplain. ${ }^{79}$ His motive: 'as Gospel messenger, Boer and British were all alike to me. ${ }^{80}$ Unlike Taylor, most male Zionist sympathizers almost certainly fought. But even these were keen to stress, at least rhetorically, that they avoided killing Boer brethren. One soldier reported to Leaves that 'I had my rifle levelled at the head of a Boer, when something said to me, "If you pull the trigger, he is a dead man"...I at once cocked my

\footnotetext{
${ }^{74}$ W.F.P. Burton, When God Makes a Missionary (London: Victory Press, 1936)

${ }^{75}$ James Opp, Lord for the Body: Religion, Medicine and Protestant Faith Healing in Canada, 1880-1930 (London: McGill-Queen's University Press, 2005), 89.

${ }^{76}$ E.B. Hawkins, The Story of Harrismith (Harrismith: Harrismith Rotary Club, 1982), 99.

${ }^{77}$ Burton, When God Makes a Missionary, 25-26.

${ }^{78}$ Leaves of Healing, October 61906.

${ }^{79}$ The Kirkwell Arcadian, June 271903.

${ }^{80}$ Leaves of Healing, September 61902.
} 
rifle in the air. ${ }^{81}$ Another soldiery correspondent attributed his terrible injury to taking up arms against his Dutch kin: 'I [saw] that war was the Devil's work, and that God never intended me to take up arms to shoot my brother. ${ }^{82}$ In the aftermath of the war, 'racial' reconciliation between Boers and Britons, and the project of forging a new white South Africanism, was pursued by politicians as well as adopted by many Protestant churches. Once again, Dowie's cosmopolitanism resonated. By 1904, the Zionist Tabernacle on Bree Street in Johannesburg was regularly packed with congregations of several hundred, ${ }^{83}$ and one member of this period proudly proclaimed 'our church in Johannesburg [is] one half Boer and one half Briton. ${ }^{, 84}$ Some Zionists even extended this cosmopolitan rhetoric - unusually for the day -to black congregants. The view of one Mrs Ward was that 'we love British and Boer and Kaffir alike, for we have all one Father, one Savior and one Guide. ${ }^{85}$

Working alongside Le Roux and Mahon, the Bryants made rapid inroads into rural black communities in the Transvaal and the Orange Free State, baptizing thousands at open-air services. White emissaries of Zion relied heavily upon a network of talented African evangelists, including individuals such as Daniel Nkonyane and Elijah Lutango, whom Le Roux and Mahon had respectively ministered to in their former denominations, and who became the main engines of this evangelistic drive, working as interpreters as well as preaching and laying hands on converts in their own right. ${ }^{86}$ Unusually for the period, these white and black proselytisers worked together in disseminating Zionist's divine healing teachings across farm lands. Yet Zionists' vision of racial fraternity - discernable in church members' determination to transcend divisions between Boer and Briton as much as in this network of white and black evangelists was a very distant ideal in turn-of-the-century Transvaal and the Orange Free State. In previous decades, sharecropping, and its rich profits for talented African farmers, had produced an upwardly mobile class who positioned themselves a new black elite, prizing individual landownership, their progressive Christian faith, and increasingly detached from chiefly

\footnotetext{
${ }^{81}$ Ibid .

${ }^{82}$ Leaves of Healing, 18 November 1905.

${ }^{83}$ Leaves of Healing, 29 July 1905

${ }^{84}$ Zion City News, 17 April 1908

${ }^{85}$ Leaves of Healing

${ }^{86}$ Cabrita, 'People of Adam', 581
} 
authority. ${ }^{87}$ Rather than subjects of ethnically and linguistically-determined polities, this Christian African elite appealed to the promises of the British Empire, optimistically viewing themselves members of a colour-blind worldwide federation that promised full rights and equal standing to all who embraced its progressive values and came to consider themselves civilized men. ${ }^{88}$ Added to this heady rhetoric of imperial citizenship, Christian mission societies' message of Christ's redeeming death for all - regardless of race - was also appropriated by African Christians as a platform for proclaiming racial, social and economic equality. ${ }^{89}$

However, in the aftermath of the South African War in 1902, a shifting political and economic mood rapidly dissipated black aspirations; South Africa's non-white population was increasingly viewed as merely cheap labour for white production and agriculture. Far from ushering in the hoped for race-blind polity, imperial rule meant increased strictures upon black mobility, as Britain sought strategic compromises with disaffected Boers, leading to the creation of a new South Africa aligned with white interests. ${ }^{90}$ The explosion of Johannesburg - now the gold metropolis of the world - necessitated vast amounts of labour, meaning that government policy tried to dislodge the wealthy African peasantry from farming into the mines. Independent African accumulation in the rural areas was now frowned upon as an obstacle to white industry. Denied land of their own, Africans were permitted to squat upon farmers' land. In return, they worked the farmer's land for several months annually, and paid him rent. It was a system designed to squeeze maximum labour out of black tenants for labour-hungry white farmers. Tenants considered idle were ejected. ${ }^{91}$ One recent Zionist convert from Wakkerstroom in the Transvaal, Muneli Ngobese, commented that 'our sorrow is that we live on land rented from the white man. We pay him rent but we have little peace. ${ }^{92}$ Underpinning this economic exploitation was a racial ideology that cast Africans as intrinsically inferior and best-suited to manual work. African self-improvement was discouraged. Government officials and white farmers both

\footnotetext{
${ }^{87}$ Campbell, Songs of Zion, 161; Tim Keegan, Facing the Storm: Portraits of Black Lives in Rural South Africa (Johannesburg, 1988), 133.

${ }^{88}$ Tim Couzens, The New African: A Study of the Life and Work of H.I.E. Dhlomo (Johannesburg, 1985).

${ }^{89}$ Richard Elphick, The Equality of Believers: Protestant Missionaries and the Racial Politics of South Africa (Charlottesville, 2012).

${ }^{90}$ Saul Dubow, 'Colonial Nationalism, the Milner Kindergarten and the rise of South Africanism, 1902-1910', History Workshop Journal, 43 (1997), 53-85.

${ }^{91}$ Pretoria, South African National Archives (hereafter SAB), LWM 30, Native Affairs Department (NAD) to NC Wakkerstroom, 29 August 1903.

${ }^{92}$ Leaves of Healing, 30 December 1905.
} 
disapproved of 'book learning' for Africans, believing industrial education of more use. ${ }^{93}$ Finally, in the first decade of the twentieth century, both Protestant and Catholic churches retreated from their former promise of equality for all believers. African ordinations slowed to a trickle, and missionaries increasingly echoed the racist views of politicians, industrialists and agriculturalists. ${ }^{94}$ Many responded by breaking away from mission-led denominations and forming independent organizations under black leadership - some linked to the North American African Methodist Episcopal Church - and widely dubbed 'Ethiopian' churches for their emphasis on black autonomy from white rule. ${ }^{95}$ The eastern Transvaal was the site of extensive Methodist activity, and thus one of the most important independent churches of this area was a former congregant Joel Msimang's Independent Methodist Church. New Ethiopian churches such as Msimang's retreated from the former rhetoric of multi-racial fellowship, instead - in this era of dashed hopes in racial inclusivity - investing in notions of black pride and self-reliance, exemplified by the word 'Ethiopian'. 96

But not all Christian Africans in areas such as these turned away from the older dream of cosmopolitanism; in an era of increasing restriction of African aspiration, Zion's inclusivist ethos was all the more welcomed by many blacks in the Transvaal and Orange Free State. Mahon's assistant, Elijah Lutango, observed that prior to the Christian Catholic Apostolic Church in Zion's arrival, the 'Gospel was preached and people received it, but there was no fellowship between the whites and the blacks...they were never one in the love of the Lord. ${ }^{97}$ But in Dowie's Zion, he found a remarkably different 'brotherly love' - this was 'the True Love which does not separate brethren because of difference in the colour of their skins. ${ }^{98}$ The practical implications of this cosmopolitan theology - Divine Healing knit humanity together - were profound; throughout the Transvaal and Orange Free State African Zionist preachers worked in remarkably collaborative, egalitarian relationships with their white superiors. Unlike other whiteled mission organizations which were increasingly dragging their foot over African ordination in this decade, the Zionist church followed a policy that 'natives should be ordained to the office of

\footnotetext{
${ }^{93}$ Pretoria, SAB, LWM 61, NC SE Division to SNA, 3 May 1904.

${ }^{94}$ Elphick, Equality of Believers.

${ }^{95}$ Campbell, Songs of Zion

${ }^{96}$ Campbell, Songs of Zion

${ }^{97}$ Leaves of Healing, 14 October 1905

${ }^{98}$ Sundkler, Zulu Zion, 40.
} 
deacon and evangelist (the highest rank outside of Zion City) ${ }^{99}$ And while this was certainly an aspiration shared by the Americans Dowie and Bryant, it also seems to have been an opinion shared by local white Zionists, especially Edgar Mahon, who lamented the style of his Dutch Reformed neighbours who had 'the Bible in one hand, the whip in the other, the whip being used in preference to the Bible.' Instead, Mahon proclaimed his own practice was to eschew 'the whip, and to actually shake hands with the natives and sit at meals with them. ${ }^{, 100}$ Evidence suggests Mahon did indeed fraternize with black colleagues in a manner largely unprecedented in missionary circles of the period. As late as 1915, Mahon's practice was to spend long evenings at his own home with his closest African co-workers - 'Deacons Mabula, Lutango and Ndebele called at our home and spent the evening with us. We spoke of things pertaining to the Kingdom, sang some hymns and just before parting about midnight spent a short season in prayer., ${ }^{101} \mathrm{~A}$ black stable boy fell ill at the Zionist headquarters outside of Harrismith run by Mahon and 'was prayed for just as earnestly and tenderly as would any of the white workers have been...for we are all one family in the Lord. ${ }^{102}$

Admittedly, this cosmopolitan ethos was limited in its longevity. White South African membership of the church fell sharply after Dowie's death in 1907 and the near-collapse of the church in Zion City. Most white Zionists migrated under the leadership of Pieter Le Roux to the newly-formed Pentecostal Apostolic Faith Mission. which rapidly retreated from Dowie's cosmopolitan vision and had soon entrenched racial segregation into its church life. ${ }^{103}$ Yet there were other attractions of Zion for its African constituency. The self-improving disciplines of Zionism - forged amidst the newly industrialized cities of Melbourne and Chicago - meshed surprisingly well with this dispossessed group of African peasantry. ${ }^{104}$ In a context where Africans were increasingly encouraged by the white administration to view themselves as members of confined ethnic politics, the Zionist church cut across many of the constraining solidarities the government was trying to inculcate amongst its black subjects. For example, Dowie's church forbade the consumption of both alcohol and tobacco. But the communal brewing of beer and its consumption undergirded hierarchical relationships between chiefs and

\footnotetext{
99 Zion City Independent, 15 July 1910 'Report of Native Workers' Conference.'

${ }^{100}$ Zion City News, 11 February 1910

${ }^{101}$ The Zulu and Basutoland Missionary, Vol, 3, No. 2, December 1915

${ }^{102}$ The Zulu and Basutoland Missionary, Vol. 1, No. 7, May 1914

${ }^{103}$ Cabrita, Empire of Healing, no page number available.

${ }^{104}$ Zion City News, 19 November 1909.
} 
subjects, and husbands and wives - which the government was keen to uphold, partly to enshrine cultural difference and thereby diminish Africans' claims to equality with whites. But one woman who felt moved by Zionist teachings in this period decided to cease brewing for her husband, even though she would 'be considered to have lost love for [him].' But the woman 'remembered the words of Jesus - "Who loveth Father and Mother more than me is not worthy of me" - and folded her hands. ${ }^{105}$ And if Divine Healing's bodily disciplines set Africans at odds with the social hierarchies of traditional society, it also engendered conflict with their white masters. Formerly employers had paid African workers in tobacco, now Zion labourers objected on the grounds of Divine Healing's ban on smoking: 'the master would threaten them, but 'no' was the answer... [they] used to be slaves of drink and tobacco. Glory to God. ${ }^{106}$ Farmers increasingly objected to Zion preachers on their farms, complaining tenants absconded from work to attend church. ${ }^{107}$ Zion's stance on relations between the races further alienated the white settler community from the church, leading local Harrismith farmers to treat Mahon and his family with contempt for 'lowering the prestige of the white race.' 108

But it was the promise of healing that became the most popular aspect of Zion's work in these areas. ${ }^{109}$ On the one hand, as much of the existing scholarship has argued, Divine Healing undoubtedly resonated with Nguni cosmologies whereby Africans viewed sickness and health as ultimately spiritual matters, not physiological predicaments. Popular thought held that while some illnesses stemmed from natural causes, certain bodily and societal afflictions resulted from spiritual causes. ${ }^{110}$ The nefarious interventions of witches could precipitate these misfortunes, ancestors, too, could visit their displeasure upon the living. ${ }^{111}$ It is hardly surprising, then, that the well-documented increasing frequency of accusations and suspicions of witchcraft in this period were a barometer for the social and economic dislocation experienced by the region's Africans. But while Zionism's identification of sickness and health as spiritual matters clearly provided a powerful parallel, these self- consciously modernizing Africans did not prize Divine

\footnotetext{
105 Zion City News, 22 October 1909.

106 Sundkler, Zulu Zion, 44.

${ }^{107}$ Pretoria, SAB, LWM 25, NC Volksrust to NC SE Division, 8 February 1904.

${ }^{108}$ Burton, When God Makes a Missionary, (will get page ref. shortly)

${ }^{109}$ Leaves of Healing, 8 October 1904.

${ }^{110}$ Karen Flint, Healing Traditions: African Medicine, Cultural Exchange and Competition in South Africa, 1820 1948 (Athens, OH, 2008), 65

${ }^{111}$ Flint, Healing Traditions, 37-66.
} 
Healing primarily for its affirmation of indigenous healing therapies. Instead, it was understood as a technique of modernizing self-improvement, part of the broader repertoire of African progressiveness and optimism that characterized this period. For all Zion's resonance with indigenous health theories, adherents knew its bodily disciplines were strictly exclusive - all faith must be placed in the Judeo-Christian God alone. This, therefore, was a spiritual discipline that detached Africans from local loyalties, setting them on an entirely different trajectory to one mapped out by indigenous concerns. A Zionist evangelist in the Transvaal 'gathered all the people together and explained the truths of Zion.' Immediately they 'took down all their medicine charms as a token from that day on they were going to live for God alone. ${ }^{112}$ Zionist Evangelist Fred Luthuli preached the necessity of renouncing local therapies for Divine Healing's superior cures: 'a woman who had been ill for a long time was treated by the native doctor. When I came to her the woman told me that the doctor could not heal her, and we threw her medicine out. ${ }^{, 13}$ Whatever the deeply-felt continuities with existing cosmologies, conversion to Zionism was cast - both by Zionist preachers and ordinary members - as a decisive break with older religious systems.

The progressive discipline of Divine Healing promised working men and women uplift and selfperfection in all areas of their lives. Thus Zion also stood for education and schooling for all, cast by Dowie as an essential aspect of the self-improvement of working people, both in the Midwest amongst industrialized Europeans and amongst laboring Africans in the Transvaal and Orange Free State. And while white opinion was highly unsympathetic to education for Africans, ${ }^{114}$ considering it supplied them with ideas above their status, Dowie instructed Bryant to 'embrace every opportunity of teaching these poor people to read and write. ${ }^{115}$ By 1905 , there were seven Zion schools in the Transvaal, with seventy six pupils, located on sympathetic farmers' land, founded by sharecropping families who had converted to the church. ${ }^{116}$ In contrast to the government's views on the desirability of manual training rather than subversive 'book learning', no industrial skills were taught by Zionist schools, which instead focused on reading, writing and

\footnotetext{
112 Zion City News, 19 November 1909.

${ }^{113}$ Leaves of Healing, 30 December 1905.

${ }^{114}$ Rand Daily Mail, 16 December 1908. VAB, ORC 332, South African Native Affairs Commission, 1903-1905, Vol. IV, Evidence of Mr Hugh Gunn (Director of Education in Orange River Colony)

${ }^{115}$ Zion, Illinois, CCC, Dowie to Bryant, 18.

${ }^{116}$ Leaves of Healing, 30 December 1905.
} 
arithmetic. ${ }^{117}$ Black Zionists celebrated any prospect of progress - this was the opinion of one Zionist parent: 'we grew up in the dark...we had no school and no teaching. But we do not want our children to be the same. 118

Finally, in a period when African aspirations to private land ownership - a key marker of modernizing self-improvement and detachment from obligations to chiefs and other traditional leaders - were disappointed, the vision of 'Zion City' - a physical sanctuary where Zionist disciplines could be practiced unmolested - resonated profoundly with black converts. Dowie had founded Zion City as a healthy haven from Chicago's urban corruption. New African converts similarly sought land to pursue their new identity as people of Zion, renouncing former societal obligations and seeking to escape racist strictures. Dowie's local representative Pieter Le Roux recognized that 'the peoples' one desire is to have a Zion City in their own country, where they can live and serve God in peace. ${ }^{119}$ In 1903, Le Roux leased land and applied to officials to build a church and school and settle fifty families 'for the spread of Christianity' upon it. ${ }^{120}$ Zionist evangelist and wealthy peasant farmer Daniel Nkonyane aspired to build a Zion church and school upon his 300 acres of land. ${ }^{121}$ There were a 'good few' Zion people living upon Nkonyane's farm, and he boasted that 'everybody in the area comes to church upon my land. ${ }^{122}$ In rural South Africa, as much as in the urban Midwest, working people drew upon Zionist practices in their pursuit of economic independence and social autonomy.

\section{Conclusion}

What, then, can be concluded from this brief comparative history of the origins of a Protestant Divine Healing movement in Illinois, USA, and its successful transmission to the farmlands of South Africa, over a century ago? This article has sought to highlight that when the two phenomena are compared side by side, important features emerge. Conversely, when the purely indigenous nature of Zionism is stressed - as is more usual, its seamless 'translation' into an African context - these aspects are invisible. This conclusion will make three brief points about

\footnotetext{
${ }^{117}$ Bloemfontein, Free State Provincial Archives (hereafter known as VAB), NdAB 1, Lieutenant Commander Orange River Colony to Adviser for Native Affairs, Bloemfontein, 10 June 1905.

118 Ibid.

${ }^{119}$ Leaves of Healing, 30 December 1905.

${ }^{120}$ Pretoria, SAB, SNA 144, Le Roux to Sub-Native Commissioner, Wakkerstroom, 29 June 1903.

${ }^{121}$ Leaves of Healing, 30 December 1905.

122 Ibid.
} 
the value of this comparative approach, and close by reflecting on its broader significance for scholarly histories of Christianity in sub-Saharan Africa as well as beyond.

In both the Midwest and rural South Africa, Zionism can only be understood as a product of the seismic social changes that gripped the globe in this period. Technological advances catalyzed the industrialization of Chicago alongside the large-scale commercial mining of gold in Johannesburg. In both contexts, turbulent social change was triggered by these processes of mechanization and industrialization; the demand for cheap, plentiful labor produced the large immigrant European ethnic enclaves of working class Chicago and also dislodged Africans from their territorial inheritances as gold-hungry mine owners attempted to coopt cheap labor. Far from Zionism in South Africa being merely a unique product of local conditions - black resistance to colonialism and apartheid, for example - we see instead that the transatlantic Zionist movement was a response to the economic and social changes wrought by industrialization, as well as part of the rich repertoire of responses concocted by urban residents in this period.

In both contexts, Zionism emerged in environments - North American and Southern African - in which bodily health was overlain with spiritual meaning. While South African Zionists' interest in healing is often cast as an extension of local healing therapies, in fact, industrializing communities on both sides of the Atlantic were prone to interpreting health and sickness in moral terms, notwithstanding important differences in their interpretations. In nineteenth-century Chicago, as in Melbourne, urban disorder was understood as a moral predicament that resulted in diseased and degenerate bodies; in the farmlands of Transvaal, disease was a symptom of the social, economic and political insecurity that gripped dispossessed agrarian African communities. Zionism was a way to address the social-spiritual implications of ill health that gained potency in an unusually turbulent social period across much of the world. It is necessary to robustly historicize Africans' interest in Protestant healing therapies in this period, rather than simplistically ascribing them to supposedly innate cultural predispositions on the part of African Christians to supernatural interpretations of health and sickness.

Finally, a comparative study of Zionism illuminates the popular saliency of cosmopolitan thought in South Africa. While political parties such as the African National Congress have traditionally been viewed as the main vehicles for multi-racial thought, in fact, a whole swathe of 
cosmopolitan practices existed beneath the radar of formal political participation. Yet Zionism has largely been identified part of a nativist, racially-exclusive strand within South African social history, an insular response on the part of besieged African communities to retreat from the broader world, and disengaged from political engagement. But a transnational lens - analyzing Zionism in South Africa alongside its precursors and companions in the USA and in Australia reveals that immigrant communities in industrializing Chicago, at the bottom of the economic ladder and socially ostracized, as well as black small-scale farmers of the Transvaal dislodged by the demands of Johannesburg, were all searching for new languages with which to assert claims as old certainties vanished. For both communities, we see the value of Zionism's cosmopolitan claim that all humanity found fraternity in a single Kingdom of God. And although the local multiracialism of the movement in South African soon fractured, Zion's internationalism was carried forward in other ways. Black South Africans maintained contact via letter correspondence with white American Zionists throughout the twentieth century (often leaning upon American brethren for strategic contacts during an era when the apartheid government was deeply suspicious of independent black churches). And in the present-day, over 40 missionaries commissioned by the descendent of Dowie's original church in Zion, USA work as theological educators amongst Zionist churches throughout Southern Africa, offering affordable opportunities for education to black ministers hungry for the legitimacy bestowed by a diploma. $^{123}$

In closing, then, while the above discussion has argued for the specific value of this approach for Zionism in South Africa, there are also broader implications for our historical understanding of Christianity in Africa and beyond. Protestantism in Africa was not insulated from broader developments in the history of Christianity. We cannot, therefore, overly lean upon categories such as African, culture and tradition in understanding African religious change in the modern period, or at any other time. While translation is an important theme to consider, in the study of Christianity in Africa the term has often become shorthand for imprecise emphases on the 'Africanness' of Christianity as an explanatory device. Our challenge now as historians of Christianity in Africa is to find better ways to describe modern Africans' experience of the

\footnotetext{
${ }^{123}$ Cabrita, Empire of Healing, no page number available
} 
modern world, as well as account for their lively dreams of horizons far beyond their immediate environments. 